\title{
Influence of Gestational Age, Cesarean Section and Hematocrit on Interleukin-8 Concentrations in Plasma and Detergent-Lysed Whole Blood of Noninfected Newborns
}

\author{
Felix Neunhoeffer ${ }^{\mathrm{a}}$ Diana Lipponer ${ }^{\mathrm{a}}$ Martin
Thorsten W. Orlikowsky ${ }^{\mathrm{c}}$

${ }^{\mathrm{a}}$ Department of Neonatology, University Children's Hospital,
${ }^{\mathrm{D}}$ Department of Medical Biometry, University of Tübingen, \\ b Department of Medical Biometry, University of Tübingen,
${ }^{c}$ Department of Neonatology, University of Aachen, Germany
}

\section{Keywords}

Interleukin-8 - IL-8 - Detergent-lysed whole blood . Hematocrit - Gestational age $\cdot$ Birth weight

\section{Summary}

Background: Sensitivity of interleukin-8 (IL-8) in detecting early-onset bacterial infection (EOBI) is high. A high percentage is bound to nonspecific receptors on erythrocytes which can be determined via cell lysis. We have shown detergent-lysed whole blood (DLWB) IL-8 to be superior to plasma IL-8 in detecting EOBI. Methods: To evaluate influence of pre- and perinatal factors on plasma and DLWB IL-8 concentrations, IL-8 was determined via ELISA (Immulite) in 146 noninfected newborns with risk factors for EOBI at two different time periods: 0-6 (group I) and 24-30 h (group II) after birth. The influence of gender, mode of delivery, gestational age and hematocrit was evaluated. Results: While we found no influence of gender or gestational age, hematocrit was positively correlated with IL-8 plasma concentration (group I: $r=0.33, p<0.001$; group II: $r=0.30$, $\mathrm{p}<0.01)$. IL-8 plasma concentrations after primary versus secondary cesarean section were lower $(p<0.05)$. Gestational age was correlated with DLWB IL-8 concentrations (group I: $r=0.46, p<0.001$; group II: $r=0.28, p<0.001$ ). Conclusion: Plasma IL-8 concentrations were positively correlated with hematocrit, whereas DLWB IL-8 concentrations increased with gestational age. This may be relevant to the interpretation of IL-8 in preterm infants and infants with anemia, polyglobulia or hematolytic diseases.

\author{
Schlüsselwörter \\ Interleukin-8 - IL- 8 - Lysiertes Vollblut . \\ Hämatokrit · Gestationsalter · Geburtsgewicht
}

\section{Zusammenfassung}

Hintergrund: Die Sensitivität von Interleukin-8 (IL-8) bei der Diagnose der frühen Form der neonatalen bakteriellen Infektion (early-onset bacterial infection; EOBI) ist hoch. Ein hoher Prozentsatz wird an nichtspezifische Rezeptoren auf Erythrozyten gebunden, welcher nach Zell-Lyse bestimmt werden kann. Wir haben gezeigt, dass Lysat-IL-8 (DLWB) bei der Diagnose der EOBI gegenüber Plasma-IL-8 überlegen ist. Methoden: Um den Einfluss von prä- und perinatalen Faktoren auf Plasma- und Lysat-IL-8 zu untersuchen, wurde bei 146 nichtinfizierten Neugeborenen mit Risikofaktoren für EOBI IL-8 mittels ELISA (Immulite) zu zwei unterschiedlichen Zeitpunkten bestimmt: 0-6 (Gruppe I) und 24-30 h (Gruppe II) nach Geburt. Der Einfluss von Geschlecht, Geburtsmodus, Gestationsalter und Hämatokrit wurde untersucht. Ergebnisse: Wir fanden keinen Einfluss von Geschlecht oder Gestationsalter auf Plasma-IL-8, der Hämatokrit korrelierte positiv mit Plasma-IL-8-Konzentrationen (Gruppe I: $r=0,33, p<0,001$; Gruppe II: $r=0,30, p<0,01$ ). IL-8-Konzentrationen in Plasma waren primärer niedriger als nach sekundärer Sectio caesarea $(p<0,05)$. Das Gestationsalter korrelierte positiv mit IL-8-Werten in Lysat: (Gruppe I: $r=0,46, p<0,001$; Gruppe II: $r=0,28 . p<0,001)$. Schlussfolgerung: Plasma-, jedoch nicht DLWB-IL-8-Konzentrationen, korrelierten positiv mit dem Hämatokrit, wohingegen IL-8 in Lysat mit dem Gestationsalter positiv korrelierte. Dieser Sachverhalt kann bei der Interpretation von IL-8-Werten von Frühgeborenen und von Kindern mit Polyglobulie, Anämie oder hämatologischen Erkrankungen relevant sein.

\begin{tabular}{ll}
\hline KARGER & @ 2011 S. Karger GmbH, Freiburg \\
Fax +497614520714 & Accessible online at: \\
Information@Karger.de & www.karger.com/tmh \\
www.karger.com &
\end{tabular}




\section{Introduction}

For the detection of both, early and late onset neonatal bacterial infection (EOBI; LOBI), cytokines play a predominant role [1]. Besides interleukin-6 (IL-6), IL-8 is a reliable, sensitive and easily accessible chemokine [2]. IL-8 is secreted within 1-3 h of endotoxin challenge [3]. As with most cytokines, its plasma half life is short, comprising less than $4 \mathrm{~h}[4,5]$. Circulating IL-8, which can be detected in plasma or serum via immunoassay, is bound immediately to two distinct high-affinity IL-8 receptors that are abundantly present on neutrophils before internalization and degradation $[6,7]$.

Circulating IL-8 only reflects a small portion of total blood IL-8 content, since $97 \%$ is cell-associated $[7,8]$ by chemokine-binding receptors such as the Duffy antigenrelated chemokine receptors (DARC) on erythrocytes [8]. DARC-ligated IL-8 is biologically inactive to neutrophils but can re-circulate due to receptor ligation by other cytokines [9] or pathogens [10, 11]. Thereby, dissolved IL-8 may retain its biological activity. Since $85 \%$ of cell-associated IL- 8 is bound on erythrocytes [8], this 'pool' may influence IL-8 plasma concentration. The sum of cell-associated plus circulating IL-8 can be determined by lysing blood cells with a detergent $[8,9]$.

We previously compared kinetics of plasma and detergentlysed whole blood (DLWB) IL-8 in healthy newborns with those found in newborns with EOBI [12]. DLWB IL-8 was more sensitive during the first $6 \mathrm{~h}$ of infection than plasma IL-8. In contrast to plasma IL-8, it remains elevated for approximately $24 \mathrm{~h} \mathrm{[12],} \mathrm{thereby} \mathrm{partially} \mathrm{bridging} \mathrm{the} \mathrm{diag-}$ nostic gap mentioned above. Also its negative predictive value to exclude EOBI was high. For preterm infants, this method appears particularly attractive as DLWB IL-8 only requires $50 \mu$ l EDTA blood.

Taking pre- and perinatal determinants of IL-8 into consideration, our patient population consisted of two main groups: late preterm ( $\geq 33$ weeks of gestational age) and full-term infants. Mode of delivery was included, assuming IL-8 concentrations of infants born via secondary cesarean section are elevated in comparison to those delivered by primary cesarean section. We tested the hypothesis that red blood cell characteristics influence IL-8 plasma and DLWB kinetics in noninfected term newborns, which may influence the therapeutic value of plasma and DLWB IL-8 in neonatal blood disorders such as anemia, hemolysis or polyglobulia.

\section{Patients and Methods}

Patients

185 neonates were enrolled with institutional ethics committee approval and parental consent in this study. Inclusion criteria were suspicion of bacterial infection based on clinical signs compatible with infection (listed below) and obstetric risk factors. Patients with co-morbidities causing elevated IL-8 concentrations such as chromosomal abnormalities or surgical intervention were excluded.

As previously described [12] indications for our observation program and blood screening were one or a combination of the following criteria: fever (rectal temperature $\geq 38.0^{\circ} \mathrm{C}$ ) or hypothermia, thermal instability, pallor, grey skin color, feeding difficulties, tachypnea or dyspnea, requirement of supplemental oxygen, respiratory insufficiency or apnea, capillary refill $>2 \mathrm{~s}$, arterial hypotension, increased or decreased muscle tonus, irritability and lethargy [13]. Obstetrics risk factors included: peripartal maternal fever, maternal leukocytosis (>12,000 granulocytes $\left./ \mathrm{mm}^{3}\right)$ and/or CRP elevation $>10 \mathrm{mg} / \mathrm{l}$ after exclusion of other foci, history of amniotic infection, vaginal smear positive for group B streptococci, premature rupture of membranes $\geq 18 \mathrm{~h}$, dystocia, foul smelling amniotic fluid, fetal tachycardia ( $>160 \mathrm{bpm})$.

Blood was drawn twice within the first 24-30 h of life, minimum time interval between the two measurements was $19 \mathrm{~h}$. In analogy to previous studies $[12,13]$, EOBI was diagnosed in the presence of at least one positive clinical sign and evidence of the following criteria: a peak C-reactive protein $(\mathrm{CRP})>10 \mathrm{mg} / \mathrm{l}$ within $24 \mathrm{~h}$ after initial clinical symptoms, leukopenia $\left(<4,000 / \mathrm{mm}^{3}\right)$ or leukocytosis $\left(>30,000 / \mathrm{mm}^{3}\right.$ first day or $>20,000 / \mathrm{mm}^{3}$ second day), increased immature-to-total neutrophil ratio $(>0.2)$ or positive blood culture. If EOBI could be excluded by clinical and laboratory monitoring (CRP levels $\leq 10 \mathrm{mg} / \mathrm{l}$, no positive blood culture), neonates were diagnosed as not being infected and enrolled in our study. 27 neonates meeting criteria for EOBI were excluded. A further 5 neonates which were retrospectively diagnosed as non-infected, but initially received antibiotics for $48 \mathrm{~h}$, were excluded.

Data collected included obstetric information, mode of delivery (spontaneous birth, primary cesarean section (section due to maternal indication; normal cardiotocography (CTG) without labor pain), secondary cesarean section [section due to pathologic CTG; existing or increased labor pain) and vacuum extraction, gender, gestational age, birth weight, clinical and laboratory information (plasma IL-8, DLWB IL-8, CRP, white and differential blood count). Blood samples were processed and analyzed within $2 \mathrm{~h}$. A prerequisite was a technically smooth venipuncture. Blood samples which were macroscopically hemolytic or processed with a delay of more than $2 \mathrm{~h}$ were excluded $(\mathrm{n}=19)$. In order to receive detailed information on the first $24-30 \mathrm{~h}$ post partum, we grouped the patients as follows: Group I includes IL- 8 concentrations measured within the first $6 \mathrm{~h}$, group II at approximately 24-30 h, mostly to confirm or exclude EOBI.

\section{Biochemical and Hematologic Determinations}

Circulating IL-8 was detected in plasma, sampled in lithium-heparin coated tubes, and results are available after $50 \mathrm{~min} .25 \mu \mathrm{l}$ plasma were diluted with $100 \mu \mathrm{l}$ (1:5) sample diluent (I8; DPC Biermann, Bad Nauheim, Germany). The detection limit of plasma IL-8 was $2 \mathrm{pg} / \mathrm{ml}$ (standardized in accordance with the National Institute for Biological Standards and Controls Reference Preparation 89/520). Inter- and intraassay variations were $<5 \%$ at $100 \mathrm{pg} / \mathrm{ml}$. Native EDTA blood, obtained for routine hematologic measurement, served as a source for DLWB IL-8. For a single determination a total of $50 \mu \mathrm{l}$ whole blood was required. A blood cell lysate was prepared immediately from each EDTA blood sample: a $0.05 \mathrm{ml}$ aliquot was mixed well with $0.05 \mathrm{ml}$ of lysis solution (buffered solution with detergent; Milena Biotec, Bad Nauheim, Germany) and incubated in stoppered $1.5 \mathrm{ml}$ polypropylene tubes for $5 \mathrm{~min}$ at room temperature [12]. The resulting lysate was used for IL-8 measurements without further centrifugation via chemiluminescence immunoassay (Immulite test code I8, DPC Biermann). Hematocrit, and hemoglobin were detected via an automated assay (Sysmex XE-2100, Norderstedt, Germany). CRP was measured by enzyme sandwich immunoassay (Vitros 250, Ortho Diagnostics, Rochester, NY, USA). Intraand inter-assay variations were $<5 \%$. 
Table 1. Patient characteristics

\begin{tabular}{lcc}
\hline & Group I & Group II \\
\hline Number of neonates & 95 & 51 \\
$\quad$ Male & $41(43.2 \%)$ & $27(52.9 \%)$ \\
Median birth weight, g (range) & $3,320(1,100-4,250)$ & $3,400(1,790-4,400)$ \\
Median gestational age, days (range) & $276(232-297)$ & $276(235-292)$ \\
Preterm & $248(232-259)$ & $251(235-259)$ \\
Term & $278(260-297)$ & $278(260-292)$ \\
\hline
\end{tabular}

Table 2. IL-8 concentrations in plasma and DLWB

\begin{tabular}{|c|c|c|c|c|c|c|}
\hline & \multicolumn{3}{|c|}{ IL-8 concentrations, pg/ml (range) } & & & \\
\hline & gro & & & \multicolumn{3}{|c|}{ group II } \\
\hline & $\mathrm{n}$ & IL-8 plasma & IL-8 DLWB & $\mathrm{n}$ & IL-8 plasma & IL-8 DLWB \\
\hline \multicolumn{7}{|l|}{ Mode of delivery } \\
\hline Spontaneous birth & 38 & $34.0(10-96)$ & $14,333(400-36,480)$ & 29 & $24.9(2-48)$ & $12,461(2,560-27,560)$ \\
\hline Cesarean section & 45 & $24.7(10-78)$ & $8,787(400-23,040)$ & 14 & $19.6(10-38)$ & $11,314(4,640-20,000)$ \\
\hline Vacuum extraction & 12 & $27.4(10-34)$ & $12,813(3,240-28,800)$ & 8 & $25.9(10-38)$ & $12,480(8,200-16,680)$ \\
\hline \multicolumn{7}{|l|}{ Gender } \\
\hline Male & 41 & $28.3(10-63)$ & $11,266(400-36,480)$ & 27 & $26.0(10-42)$ & $12,042(2,560-19,680)$ \\
\hline Female & 54 & $30.8(10-93)$ & $11,702(400-28,800)$ & 24 & $22.0(2-45)$ & $12,268(4,640-27,560)$ \\
\hline
\end{tabular}

Table 3. IL-8 concentrations in plasma and DLWB in newborns delivered by primary versus secondary cesarean section

\begin{tabular}{|c|c|c|c|c|}
\hline & \multicolumn{2}{|l|}{ Group I } & \multicolumn{2}{|l|}{ Group II } \\
\hline & primary & secondary & primary & secondary \\
\hline Number of neonates & 16 & 29 & 5 & 9 \\
\hline Median IL-8 plasma, pg/ml (range) & $19.1(10-42)$ & $32.0(10-79)$ & $20.2(13-30)$ & $28.1(10-96)$ \\
\hline Median IL-8 EDTA, pg/ml (range) & $6,227(400-15,240)$ & $10,199(3,680-23,040)$ & $12,400(6,600-19,680)$ & $10,711(4,640-16,680)$ \\
\hline
\end{tabular}

\section{Statistical Analysis}

Data were expressed as median and ranges. For data analysis, MannWhitney U test was applied. To examine the relationship between IL-8, gestational age and hematocrit, scatter plots were used and Spearman's rank correlation coefficients were calculated. All charts were created with SigmaPlot (SPSS, Chicago, IL, USA).

\section{Results}

\section{Patients}

Follow-up was completed in 146 non-infected neonates with pre- or perinatal risk factors and/or symptoms compatible with EOBI. 39 additional neonates were excluded: 27 of them showed clinical signs for EOBI and an elevated CRP concentration $>10 \mathrm{mg} / \mathrm{l}$ for more than $24 \mathrm{~h}$, one had a positive blood culture, 5 received ex iuvantibus therapy with antibiotics and 7 had an incomplete data record. Patient characteristics are presented in table 1. Group I comprised 95 neonates (43\% male, 73 term, 22 preterm), group II 51 neonates (53\% male, 46 term, 5 preterm).

\section{Influence of Gender and Mode of Delivery}

In noninfected neonates, median DLWB IL-8 concentrations were $400-500 \%$ higher than mean IL-8 concentrations in plasma in group I and II. Gender did not influence plasma or DLWB IL-8 concentrations ( $p>0.05$; table 2 ).

Dividing mode of delivery into spontaneous births, vacuum extractions, or cesarean sections, no differences in IL-8 concentrations were evident ( $p>0.05$; table 2$)$, suggesting that the delivery mode did not influence the IL- 8 concentrations.

Regarding cesarean sections, median plasma IL-8 concentrations from neonates delivered by primary section in group I were $19.1 \mathrm{pg} / \mathrm{ml}$. These values were lower than those 
Table 4. Plasma and DLWB IL-8 in preterm and term neonates

\begin{tabular}{|c|c|c|c|c|}
\hline & \multicolumn{2}{|l|}{ Group I } & \multicolumn{2}{|l|}{ Group II } \\
\hline & preterm & term & preterm & term \\
\hline Median gestational age, days (range) & $248(232-259)$ & $278(260-297)$ & $251(235-259)$ & $278(260-292)$ \\
\hline Number of neonates & 22 & 73 & 5 & 46 \\
\hline Median IL-8 plasma, pg/ml (range) & $27.6(10-63)$ & $29.3(10-93)$ & $22.8(10-45)$ & $24.1(2-96)$ \\
\hline Median IL-8 DLWB, pg/ml (range) & $5,934(400-17,520)$ & $13,199(400-36,480)$ & $6,456(4,920-16,320)$ & $12,768(2,560-27,560)$ \\
\hline
\end{tabular}

Fig. 1. Influence of gestational age on IL-8 concentrations in plasma in group I (upper panel left; $\mathrm{r}=0.199 ; \mathrm{p}=0.054)$ and group II (upper panel right; $\mathrm{r}=0.173$; $\mathrm{p}=0.223)$ and DLWB in group I (lower panel left; $r=0.499$; $\mathrm{p}<0.001)$ and group II (lower panel right; $\mathrm{r}=0.251 ; \mathrm{p}<0.01)$
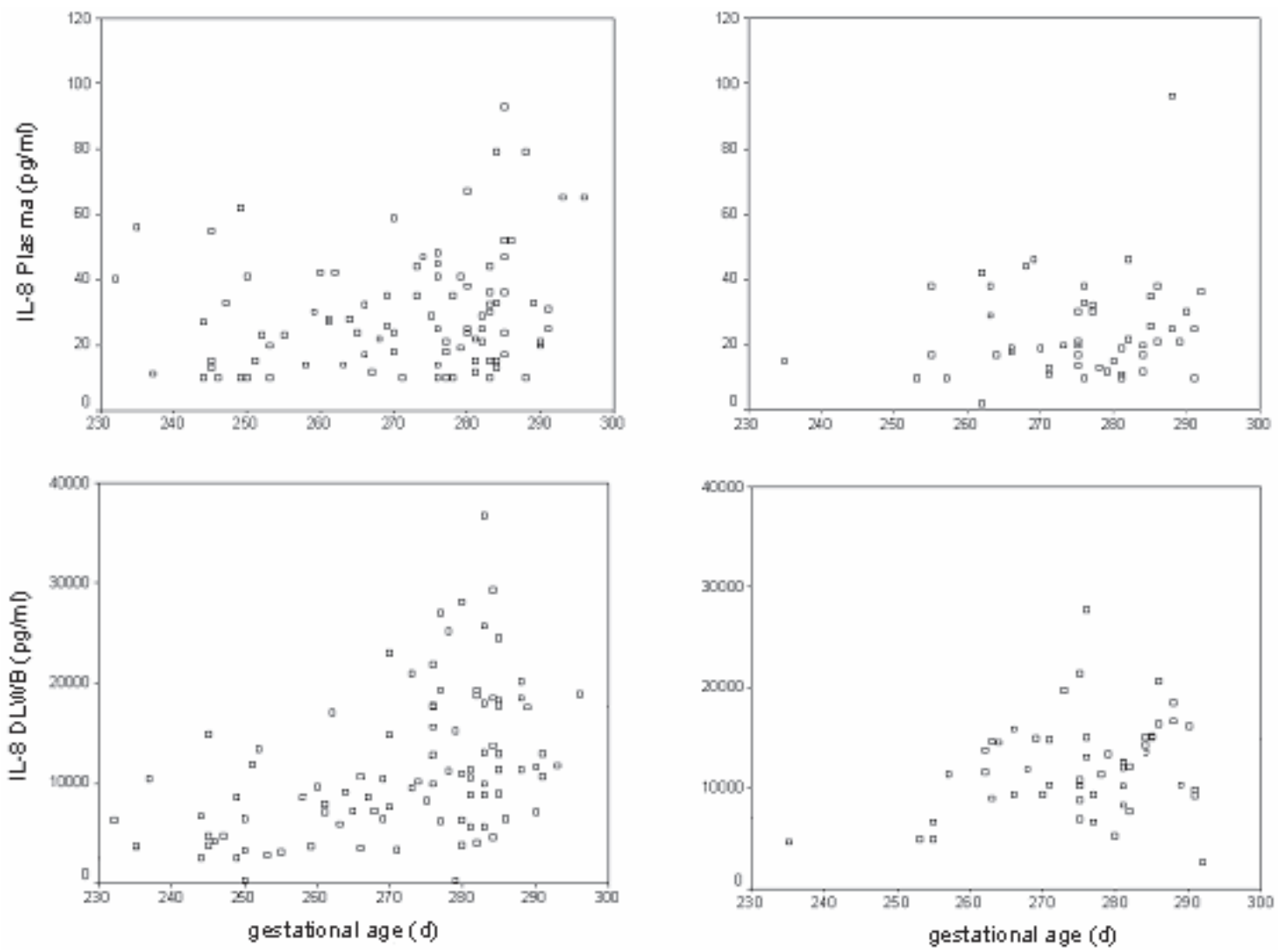

from neonates delivered by secondary section $(32.0 \mathrm{pg} / \mathrm{ml}$ $(\mathrm{p}<0.001$; table 3$)$. The same phenomenon held true in group II with $20.2 \mathrm{pg} / \mathrm{ml}$ versus $28.1 \mathrm{pg} / \mathrm{ml}(\mathrm{p}<0.05$; table 3$)$.

Median DLWB IL-8 concentrations in group I showed differences with $6,227 \mathrm{pg} / \mathrm{ml}$ following primary and 10,199 $\mathrm{pg} / \mathrm{ml}$ following secondary section $(\mathrm{p}<0.001$; table 3$)$. In contrast to plasma IL-8, this difference was no more evident after 24-30 h, with median DLWB IL-8 concentrations of 12,400 $\mathrm{pg} / \mathrm{ml}$ versus $10,711 \mathrm{pg} / \mathrm{ml}$ (table 3 ).

\section{Influence of Gestational Age}

DLWB IL-8 concentrations were influenced by gestational age in group $\mathrm{I}(\mathrm{r}=0.499 ; \mathrm{p}<0.001)$ and group II $(\mathrm{r}=0.251$; $\mathrm{p}<0.01)$ as shown in figure 1 . Median values for preterm neonates in group I were $5,934 \mathrm{pg} / \mathrm{ml}$ versus $13,199 \mathrm{pg} / \mathrm{ml}$ for term neonates and in group II 6,456 pg/ml versus 12,768 $\mathrm{pg} / \mathrm{ml}$ (table 4). We found no influence on plasma IL-8 concentrations for gestational age ( $p>0.05)$. Median values for preterm neonates in group I were $27.6 \mathrm{pg} / \mathrm{ml}$ versus $29.3 \mathrm{pg} / \mathrm{ml}$ for term neonates and in group II $22.8 \mathrm{pg} / \mathrm{ml}$ versus $24.1 \mathrm{pg} / \mathrm{ml}$ (table 4$)$.

\section{Influence of Hematocrit}

In both groups, plasma IL-8 concentrations were positively correlated with the hematocrit (group I: $\mathrm{r}=0.331, \mathrm{p}<0.001$; group II: $r=0.332, p<0.05$; fig. 2 ): in group I and group II median plasma IL-8 concentrations were $29.7 \mathrm{mg} / \mathrm{dl} 24.2$ $\mathrm{pg} / \mathrm{ml}$, respectively; the respective median hematocrit values were $52.3 \%$ and $50.2 \%$. DLWB IL-8 concentrations were not influenced by the hematocrit ( $p>0.05$ ), with median DLWB IL-8 concentrations of $11,513 \mathrm{pg} / \mathrm{ml}$ in group I and 12,149 $\mathrm{pg} / \mathrm{ml}$ in group II. 

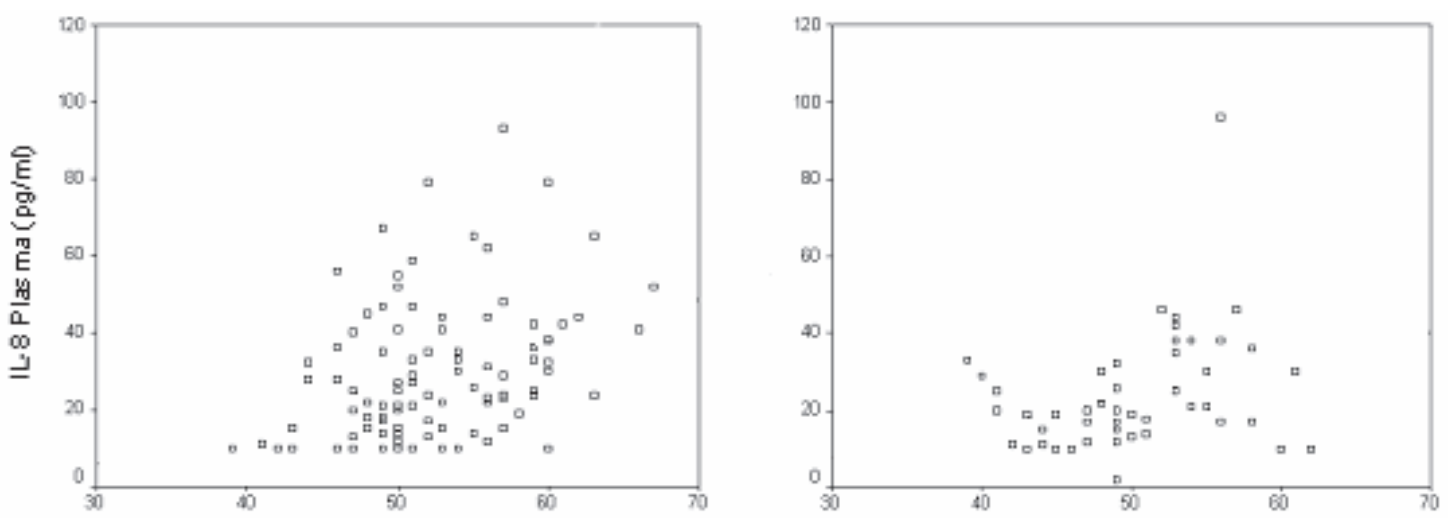

Fig. 2. Influence of hematocrit on IL-8 concentrations in plasma in group I (upper panel left; $\mathrm{r}=0.331 ; \mathrm{p}<0.001)$ and group II (upper panel right; $\mathrm{r}=0.332$; $\mathrm{p}<0.05)$ and DLWB in group I (lower panel left; $r=0.172$; $\mathrm{p}=0.095)$ and group II (lower panel right; $\mathrm{r}=-0.106 ; \mathrm{p}=0.459)$
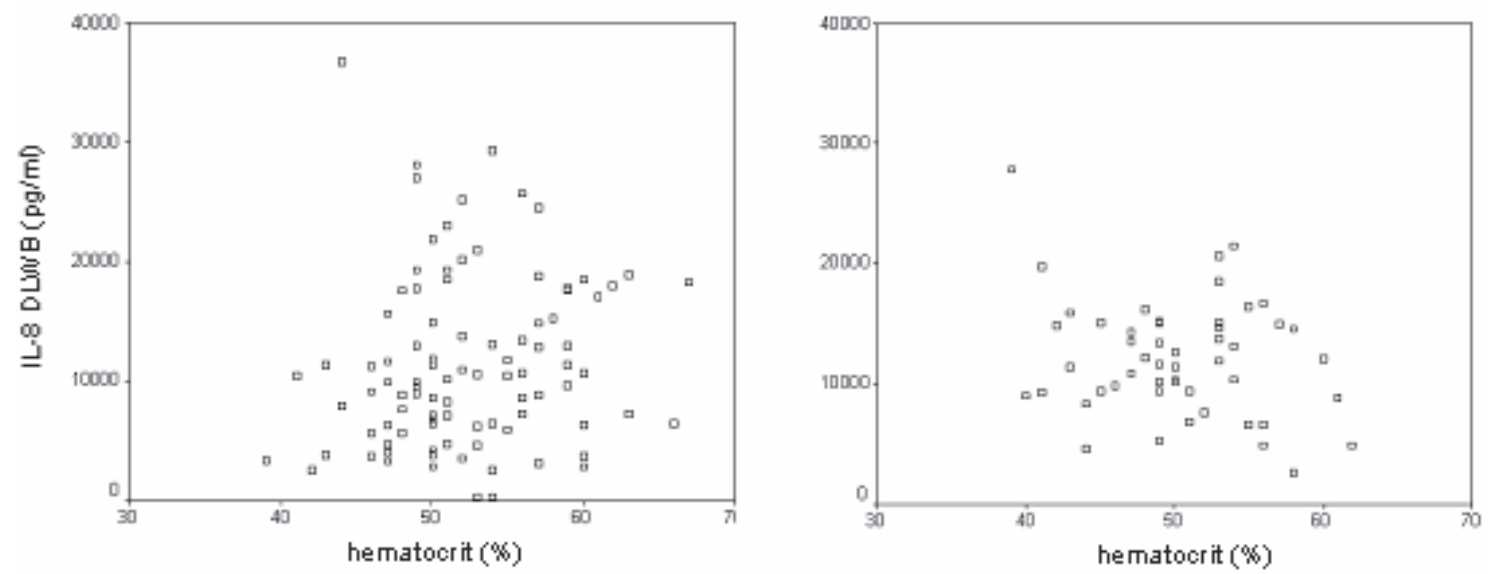

\section{Discussion}

We found the hematocrit to be positively correlated with plasma IL-8 concentrations (group I: $\mathrm{r}=0.331$, $\mathrm{p}<0.001$; group II: $\mathrm{r}=0.332, \mathrm{p}<0.05)$. Plasma concentrations were lower if newborns were delivered via primary cesarean sections. Of the parameters investigated, gestational age was correlated with DLWB IL-8 concentrations (group I: $r=0.499$, $\mathrm{p}<0.001$; group II: $\mathrm{r}=0.251, \mathrm{p}<0.01$ ).

Conventional tests have limitations in identifying infections in newborns. There is a rapidly increasing demand for standardized tests, including flow cytometric techniques, for the detection of neonatal infection requiring minimal amounts of blood. A variety of parameters, including receptors on monocytes [15-17], cytokines and proteins, are expressed or secreted differently in full or preterm neonates and are influenced by perinatal confounders $[18,19]$.

Therefore the aim of our study was to evaluate the influence of mode of delivery and hematocrit on IL-8 plasma and DLWB concentrations in term and preterm neonates. Compared with plasma IL-8, DLWB IL-8 offers the advantages that tests require smaller sample volumes and are not altered by hemolysis [20]. In agreement to other studies [19, 21, 22] we found that IL- 8 concentrations in plasma and DLWB were not influenced by gender.
In the first $6 \mathrm{~h}$ post partum there were significant differences in plasma and DLWB IL-8 concentrations between neonates delivered by primary and those delivered by secondary cesarean section (table 3 ). In plasma this difference was still evident $24 \mathrm{~h}$ post partum, but not for DLWB. Labor pain is known to influence IL-8 production [23]; in a recent study Jokic et al. [24] reported that IL-8 concentrations are less influenced by mode of delivery than by the existence and duration of labor pain. In our group of spontaneous births (table 2), we also registered the duration of labor and found no correlation between either DLWB or plasma IL-8 concentrations (not shown); however, we did not analyze or standardize labor pain. Dembinski et al. [28] found more evident neonatal proinflammatory response to labor stress in concentrations of IL-8 in whole blood than in serum.

Besides the influence of labor pain, which is also described by others $[25,26]$, delivery as such may lead to elevated plasma IL-8 concentrations via mediators of stress and anxiety. van Gool et al. [27] showed a significant increase in early postnatal plasma IL-8 concentrations if delivery was recognized as a traumatic event by the mother.

As practical consequences of our results, one would have to assume that the threshold of values for plasma IL- 8 would be lower if newborn were delivered via primary section. 
In agreement with observations of Dembinksi et al. [28] plasma IL-8 was not influenced by gestational age, in contrast to DLWB IL-8; late preterm neonates had lower DLWB IL-8 concentrations (fig. 1). This might be attributed to immaturity [29], but could also be seen as an epiphenomenon for reasons leading to preterm delivery (e.g. HELPP syndrome, gestational diabetes mellitus, placental dysfunction). Hematocrit values were not different between preterm and term infants (not shown). Thus, in analogy to reduced expression of blood type antigens, binding receptors, including Duffy antigen related chemokine receptors (DARC) on erythrocytes [8], might as well be reduced. Our data suggest that the hematocrit influences plasma IL-8 concentrations in noninfected newborns in the first $24 \mathrm{~h}$ (fig. 2).

Kinetics of DLWB IL-8 is not completely understood. DLWB IL-8 concentrations were higher than plasma IL-8 concentrations, ranging from 400 to $36,680 \mathrm{pg} / \mathrm{ml}$. Our results were similar to those of Franz et al. [13] and reflected the fact that only $1-4 \%$ of IL- 8 is dissolved in plasma [12]. Another reason for this finding is the fact that DLWB IL-8 is not only bound to erythrocytes but also to a smaller amount of about $15 \%$ to blood cells such as granulocytes, monocytes etc. [30]. Our previous studies showed normal levels for DLWB IL-8 concentrations of $<18,000 \mathrm{pg} / \mathrm{ml}$ [12].
Our investigation again reveals the problem of an ideal population and the definition of infected versus noninfected newborns: Despite existing risk factors and indefinite shortlasting clinical signs, we excluded EOBI via CRP and the clinical course. Although the clinical work-up was mostly performed by experienced neonatologists, we are aware of intrinsic restrictions related to heterogeneity of patients, limited comparability to other studies or dependence on physicians' experience. The CRP cut-off applied in our study $(10 \mathrm{mg} / \mathrm{l})$ is arbitrary but has been used by other investigators [31].

Plasma IL-8 concentrations increase with hematocrit and with secondary cesarean section as compared to primary section. In contrast, DLWB IL-8, a highly specific and sensitive parameter to detect EOBI [12] and LOBI [20] is less influenced by the hematocrit. This has to be considered in the interpretation of plasma IL-8 of newborns with anemia, polyglobulia or hematolytic diseases such as blood incompatibility of mother and child, icterus praecox or hyperbilirubinemia and should be investigated prospectively.

\section{Disclosure Statement}

The authors declare no conflict of interest

\section{References}

1 Gesellschaft für Neonatologie und pädiatrische Intensivmedizin (GNPI), AWF-Leitlinien-Register Nr. 024/008, Entwicklungsstufe: 2k. Bakterielle Infektionen bei Neugeborenen. Erstellungsdatum 06/1997. www.uni-duesseldorf.de/AWMF/ll/024008.htm.

2 Franz AR, Kron M, Pohlandt F, Steinbach G: Comparison of procalcitonin with interleukin 8 , C-reactive protein and differential white blood cell count for the early diagnosis of bacterial infections in newborn infants. Pediatr Infect Dis J 1999;18: 666-671.

3 Martich GD, Danner RL, Ceska M, Suffredini AF: Detection of interleukin 8 and tumor necrosis factor in normal humans after intravenous endotoxin: the effect of antiinflammatory agents. J Exp Med 1991; 173:1021-1024.

4 Redl H, Schlag G, Bahrami S, Schade U, Ceska M, Stutz P: Plasma neutrophil-activating peptide-1/ interleukin-8 and neutrophil elastase in a primate bacteremia model. J Infect Dis 1991;164:383-388.

$\checkmark 5$ Redl H, Schlag G, Bahrami S, Dinges HP, Schade $\mathrm{U}$, Ceska M: Markers of endotoxin related leukocyte activation and injury mechanisms. Prog Clin Biol Res 1991;367:83-100.

6 Holmes WE, Lee J, Kuang WJ, Rice GC, Wood WI: Structure and functional expression of a human interleukin-8 receptor. Science 1991;253:1278-1280.

7 Murphy TM, Tiffany HL: Cloning of complementary DNA encoding a functional human interleukin-8 receptor. Science 1991;253:1280-1283.

$>8$ Darbonne WC, Rice GC, Mohler MA, Apple T, Hebert CA, Valente AJ, Baker JB: Red blood cells are a sink for interleukin 8 , a leukocyte chemotaxin. J Clin Invest 1991;88:1362-1369.
9 Reinsberg J, Dembinski J, Dorn C, Behrendt D, Bartmann P, van Der Ven H: Determination of total interleukin-8 in whole blood after cell lysis. Clin Chem 2000;46:1387-1394.

10 Hesselgesser J, Chitnis CE, Miller LH, Yansura DG, Simmons LC, Fairbrother WJ, Kotts C, Wirth C, Gillece-Castro BL, Horuk R: A mutant of melanoma growth stimulating activity does not activate neutrophils but blocks erythrocyte invasion by malaria. J Biol Chem 1995;270:11472-11476.

11 Lachgar A, Jaureguiberry G, Le Buenac H, Bizzini B, Zagury JF, Rappaport J, Zagury D: Binding of HIV-1 to RBCs involves the Duffy antigen receptors for chemokines (DARC). Biomed Pharmacother 1998;52:436-439.

12 Orlikowsky TW, Neunhoeffer F, Goelz R, Eichner M, Henkel C, Zwirner M, Poets CF: Evaluation of IL-8-concentrations in plasma and lysed EDTAblood in healthy neonates and those with suspected early onset bacterial infection. Pediatr Res 2004;56:1-6.

13 Franz AR, Sieber S, Pohlandt F, Kron M, Steinbach G: Whole blood interleukin 8 and plasma interleukin 8 levels in newborn infants with suspected bacterial infection. Acta Pediatr 2004;93:648-653.

14 Muenzenmaier M, Depperschmid M, Gille G, Poets CF, Orlikowsky TW: C-reactive protein, detected with a highly sensitive assay, in non-infected newborns and those with early onset infection. Transfus Med Hemother 2008;35:37-41.

15 Orlikowsky TW, Dannecker GE, Spring B, Eichner M, Hoffmann MK, Poets CF: Effect of dexamethasone on $\mathrm{B} 7$ regulation and $\mathrm{T}$ cell activation in neonates and adults. Pediatr Res 2005;57:656661.
6 Gille C, Spring B, Tewes LJ, Löffler J, Dannecker GE, Hoffmann MK, Eichner M, Poets CF, Orlikowsky TW: Diminished response to interleukin-10 and reduced antibody-dependent cellular cytotoxicity of cord blood monocyte-derived macrophages. Pediatr Res 2006;60:152-157.

17 Gille C, Leiber A, Spring B, Kempf VA, Loeffler J, Poets CF, Orlikowsky TW: Diminished phagocytosis-induced cell death (PICD) in neonatal monocytes upon infection with Escherichia coli. Pediatr Res 2008;63:33-38.

18 Ng PC: Diagnostic markers of infection in neonates. A comprehensive review summarizing the evolution of infection markers in neonatology over the past two decades. Arch Dis Child Fetal Neonatal Ed 2004;89:229-235.

19 Chiesa C, Signore F, Assumma M, Buffone E, Tramontozzi P, Osborn JF, Pacifico L: Serial measurements of C-reactive protein and interleukin-6 in the immediate postnatal period: reference intervals and analysis of maternal and perinatal confounders. Clin Chem 2001;47:1016-1022.

20 Franz AR, Sieber S, Pohlandt F, Kron M, Steinbach G: Whole blood interleukin 8 and plasma interleukin 8 levels in newborn infants with suspected bacterial infection. Acta Pediatr 2004:93:648-653.

21 Krueger M, Nauck MS, Sang S, Hentschel R, Wieland H, Berner R: Cord blood levels of interleukin- 6 and interleukin- 8 for the immediate diagnosis of early-onset infection in premature infants. Biol Neonate 2001;80:118-123.

22 Malamitsi-Puchner A, Sarandakou A, Tziotis J, Economou E, Protonotariou E, Rigopoulou O× Chemokines Rantes and interleukin- 8 in the perinatal period: changes in serum concentrations. Am J Perinatol 2004;21:235-240. 
23 Yektaei-Karin E, Moshfegh A, Lundahl J, Berggren V, Hansson LO, Marchini G: The stress of birth enhances in vitro spontaneous and IL-8induced neutrophil chemotaxis in the human newborn. Pediatr Allergy Immunol 2007;18:643-651.

24 Jokic M, Guillois B, Cauquelin B, Giroux JD, Bessis JL, Morello R, Levy G, Ballet JJ: Fetal distress increases interleukin- 6 and interleukin- 8 and decreases tumour necrosis factor-alpha cord blood levels in noninfected full-term neonates. BJOG 2000;107:420-425.

25 Elliott CL, Slater DM, Dennes W, Poston L, Bennett PR: Interleukin 8 expression in human myometrium: changes in relation to labor onset and with gestational age. Am J Reprod Immunol 2000;43: 272-277.
26 Steinborn A, Sohn C, Sayehli C, Baudendistel A, Hüwelmeier D, Solbach C, Schmitt E, Kaufmann M: Spontaneous labour at term is associated with fetal monocyte activation. Clin Exp Immunol 1999; 117:147-152.

27 Van Gool J, van Vugt H, Helle M, Aarden A: The relation among stress, adrenalin, interleukin-6 and acute phase proteins in the rat. Clin Immunol Immunopathol 1990;57:200-210.

28 Dembinski J, Behrendt D, Heep A, Dorn C, Reinsberg J, Bartmann P: Cell-associated interleukin-8 in cord blood of term and preterm infants. Clin Diagn Lab Immunol 2002;9:320-323.
29 Sullivan SE, Staba SL, Gersting JA, Hutson AD, Theriaque D, Christensen RD, Calhoun DA: Circulating concentrations of chemokines in cord blood, neonates, and adults. Pediatr Res 2002;51: 653-657.

30 De Winter RJ, Manten A, De-Jong YP, Adams R, Van-Deventer SJ, Lie KI: Interleukin 8 released after acute myocardial infarction is mainly bound to erythrocytes. Heart 1997;78:598-602.

31 Orlikowsky TW, Trüg C, Neunhoeffer F, Deperschmidt M, Eichner M, Poets CF: Lipopolysaccharide-binding protein in noninfected neonates and those with suspected early-onset bacterial infection. J Perinatol 2006;26:115-119. 